\title{
The Influence of Nationalists to the Early Phase of Sinicization of Marxism
}

\author{
Zhiwu Zhou \\ Academy of Marxism, Guangdong University of Foreign Studies, Guangzhou, China \\ Email: 542921835@qq.com
}

How to cite this paper: Zhou, Z. W. (2017). The Influence of Nationalists to the Early Phase of Sinicization of Marxism. Chinese Studies, 6, 167-172.

https://doi.org/10.4236/chnstd.2017.63016

Received: December 1, 2016

Accepted: May 2, 2017

Published: July 19, 2017

Copyright (C) 2017 by author and Scientific Research Publishing Inc. This work is licensed under the Creative Commons Attribution International License (CC BY 4.0).

http://creativecommons.org/licenses/by/4.0/

\begin{abstract}
The process of spreading, developing and realizing Marxism in China is the process of combing the basic principles of Marxism with China's actual conditions. During the early phase of localizing Marxism in China, nationalists translated and explained Marxist classic works, and then spread, analyzed and applied Marxism, making great contribution to the communication of it. Their researches and promotion of Marxism, along with the influence to intelligentsia of the time, had an impact on the sinicization of Marxism objectively.
\end{abstract}

Keywords

Nationalist, The Early Phase of Sinicization of Marxism, Influence

\section{Introduction}

The early phase of sinicization of Marxism means introducing Marxism to China and then making the preliminary application to the Chinese Great Revolution. The sinicization of this phase can be viewed as the bedrock of following process, which has both theoretical and practical significance to the academic research of sinicization of Marxism (Chen Liugen \& Peng Hongyun, 2009). The communication of Marxism in China began in the early 20th century. Sun Yatsen and some other early nationalists took the responsibility of spreading it and became the precursors. Then during May fourth movement period, the spreading of Marxism embarked upon a peak period. It was found that the great promotion of Marxism from nationalists coincided with the method of early Chinese communists, which formed powerful force of public opinion and thereby stood out from many ideas. Zhu Zhixin, Dai Jitao, Hu Hanmin and some other nationalists can be regarded as the main representatives of promotion. This article will start the rudimentary discussion about the influence of nationalists to the early phase of sinicization of Marxism, in order to ask for advice from others. 


\section{The Influence of Nationalists to the Early Phase of Sinicization of Marxism}

\subsection{Nationalists Expose Many Drawbacks of Capitalist States of Europe and America, and Meanwhile, Attempt to Discuss the Construction of Socialism in China, So That It Will Avoid the Problem of the Excessive Gap between the Rich and the Poor. It Widens the Horizon of People, Creating the Theoretical Atmosphere for the Following Advanced Intellectuals to Accept Marxism}

From the late 19th century to early 20th century, Sun Yat-sen traveled to Europe and America twice, and he saw many social problems of capitalism. Sun pointed out that even though capitalist states of Europe and America had strong countries and thorough forms of government, their citizens were in poverty, with the excessive gap between the wealthy and the poor. In despite that calling for equality is loud and clear, it was stuck in empty talk. The reason why it became like this could be attributed that capitalists used great amount of money to manipulate political power throughout the country. Besides, he further pointed out that the civilization of capitalism from Europe and America could lead to both the good and the evil. The good was enjoyed by the wealthy, while the poor only suffered from the evil. That the minority controlled the civilization and happiness resulted in this unequal world. Eventually, the strike of working-class alliance, non-government parties and social parties gradually emerged, referring that "the social revolution is coming soon" (Sun Yat-sen, 1984). It indicated that during learning western countries, Sun and other revolutionists had seen the various drawbacks generated from capitalism. Then they contemplated and formed the criticism to this institution, showing empathy to the related movements.

As a follower of Sun Yat-sen, Dai Jitao was deeply affected by Sun, and fearlessly exposed the dark side of the society, revealing the reason of gap between the rich and the poor. And he looked forward to establishing a happy and peaceful socialist society. In December 1910, he published socialism theory in Tianduo Newspaper, pointing out that there is a excessive gap between the wealthy and the poor, but the disaster of the society as well as the pain of the citizens should be the result of the inequality between classes, rather than the underdevelopment of study or technology. Thus, Dai offered a suggestion to deal with this problem, which is to make socialism replace the current one, and he reckoned it as the joyous news boding well for the human beings (Tang Wenquan \& Sang Bing, 1990).

Zhu Zhixin, another nationalist, unveiled the invasive characteristic of capitalist powers in the aspect of economy. He thought that the invasion of capitalist powers is to plunder surplus value of other countries, which was the origin making the world far from tranquility. And he further illustrated that the origin of emergence of rogues and bandits in China, should be definitely attributed to the economic organization and situation. If there were no capitalists exploiting 
labour class, it would not result in bandits and rogues who robber capitalists themselves (Historical Laboratory of Guangdong Institute of Philosophy and Social Science, 1979).

\subsection{Nationalists Translate and Explain Marxist Classic Works, Widening the Promotion of Marxism, so as to Let More People Learn the Fundamental Principle of Marxism. As a Matter of Fact, the Theory Source Was Provided for Localizing Marxism in China, Becoming the Driving Force behind the Popularity of Sincization of Marxism}

Before May forth movement, there were few systematic articles concerning with Marxism. Besides, the theory itself was so abstruse that it's hard for the public to understand, raising a feeling of reverence. Hu Hanmin once said that there was no treatise specially on Marx's view of history, hence, people would probably get lost. Even some renowned economists and socialists could make some mistakes in explanation, resulting in improper criticism (Hu Hanmin, 1919). During May forth movement, $\mathrm{Hu}$ and Li Dazhao, along with other intellectuals, began working together to study Marxism and translate some works of Marx and Engels, systematically introducing Marxism to the public. In 1919, Hu translated Holy Family, The Poverty of Philosophy, Manifesto of The Communist Party, Wage labor and capital, The Eighteenth Brumaire of Louis Bonapa, Capital, etc. Meanwhile, Dai Jitao translated The Economic Doctrines of Karl Marx, written by Karl Kautsky, and serialized it on the No. 4, No. 5 and No. 6 of Volume 1, the No. 2, No. 3 and No. 5 of Volume 2, for Construction Journal. All mentioned above played a pivotal role in helping people learn the doctrines of Marxism.

What's more, nationalists pay attention to explaining Marxism as well. $\mathrm{Hu}$ wrote the article Criticism for The Criticism of Historical Materialism on the Construction Journal, which was one of the most significant theory journals of nationalist party. This article was treated as the paramount theoretic treatise during the communication of historical materialism in the period of May forth movement (Tang Baolin, 1998). Thereinto, Hu analyzed the reason why Marx and Engels could create historical materialism. From the standpoint of plebeian class, he said that the historical materialism of Marx and Engels is the embodiment of the philosophy of plebs and labors. Dai highly praised the economic principles of Marx. And he once said that among all theories concerning with the reason of increase of economy, the core of any social phenomena, the analysis of evolution, and the method guiding social reform, the theory of Karl Marx could be seen as the most tremendous one. His doctrines on goods, currency, value and surplus value, was a gigantic contribution of economics of modern times (Tang Wenquan \& Sang Bing, 1990).

May forth movement was the climax period of promotion of nationalists for Marxism. And the promotion contained labor, class struggle, socialism, women's liberation and Russian Revolution. During this time, Zhu Zhixin constantly published Careerists and Laboring Class, Combination of The Middle Society, Crisis of The New Culture, and some other related articles to introduce class struggle 
of Marxism theory. Dai also published many articles on several renowned journals, such as Weekly Review, Construction, New Youth, The Republic of China Daily supplement and Consciousness. And he published approximately 130 articles for one year on Weekly Review, which was under his general editorship. All of his essays covered various aspects of Marxism. In addition, as Weekly Review had a radical content and clear viewpoint, it was adored by lots of intellectuals, causing a sharp increase on its sale. And many progressive leagues listed it as one of must-read journals. Thus, Weekly Review made a great difference, gradually becoming the theoretical base of the early communists and popularization of Marxism.

\subsection{Facing Different Situation of Semi-Colonial and Semi-Feudal Society, Nationalists Used Some Principles of Marxism to Analyze the Issue of Country, Getting Several Conclusions from It. Therefore, It Inspired the Sinicization of the Early Phase of Marxism}

Living in the semi-colonial and semi-feudal region, people experienced weakness of the country, poverty of the public, and arrogance of the imperialism. So nationalists attempted to use Marxism's economics to explain this kind of issues, unveiling the origin of it. And it was thought-provoking for the minimum program put forward on the 12th Chinese communist party congress. Dai pointed out in Observing Origin of Chinese Issue from The Aspect of Economy that, problems emerging in western societies, could be attributed to the machine production organized by local capitalists, while the problem in China, was rooted in the machine production organized by foreign capitalists (Tang Wenquan \& Sang Bing, 1990).

When coming to the solution to problems of China, nationalists thought they could use theory of class struggle to deal with Chinese revolution. They preferred to take radical and conscious way to push violent revolution, rather than reform. It showed similarity with communist belief, which was firmly in favor of revolution by violent way. Dai pointed out in Student Strike and Revolution that, China needed man-made and conscious evolution, instead of natural and unconscious evolution. Because if Chinese didn't try "radical evolution", they would lose where they exist in global cultural life. Dai called on workers and awaken their awareness, hoping to use class struggle to rescue their lives. So class struggle could be seen as an inevitable fate in the social institution (Tang Wenquan \& Sang Bing, 1990). Zhu analyzed the class struggle of China as well. He thought despite that there was no capitalist with abundant strength in China, the method to achieve surplus value by little capitalist was tenfold effective over that of large capitalists in western countries. As a result, labors in China suffered more than people in other countries, which was required to encourage them fight against bourgeoisie (Historical Laboratory of Guangdong Institute of Philosophy and Social Science, 1979).

When coming to how to achieve final victory of class struggle, Dai proposed that mental workers and physical workers should stand together to change their 
situation. "Mental workers with knowledge should stand with physical workers lack of literacy, organizing confederate of the proletariat. They are supposed to endeavor to elevate themselves," he said (Tang Wenquan \& Sang Bing, 1990). It made a great impact on the construction of revolutionary united front.

In addition, nationalists also tried to use historical materialism to explain issues of society and morality. In Contemplation after being Huzhou, Dai analyzed the element of social life in Huzhou, based on the point that social existence determines social consciousness of historical materialism. He thought that Huzhou was divorced from the shared society based on family association, turning to individualism. Therefore, the old familism was declining and falling. Besides Li Dazhao, Dai was one of earliest forerunners who tried to explain moral issues of China by means of historical materialism, which was of great significance.

\subsection{They Criticized Some Western Scholars and Opportunists Who Reproached Marx's Historical Materialism. It Put the Record Straight for the Communication of Marxism in China}

As the advanced theory, Marxism was probably under various kinds of attack. The criticism to these false allegations could help the mass of China distinguish right from wrong, becoming the driving force behind the communication of Marxism in China. In these aspects, nationalists did a lot of work.

As for some western scholars and opportunists who reproached Marx's historical materialism, Hu categorized these faults into nine types, and focused on criticizing and refuting. For instance, Bardmovsky declined the point that economic base determines everything. But $\mathrm{Hu}$ argued that what Bardmovsky saw was subjectivism, which was at odds with what he had claimed himself as objective materialist. Besides, Bardmovsky thought class struggle was the consequence of profit, reputation and politics. But $\mathrm{Hu}$ said that the outburst of the first world war showed that the largest driving force was to fight for markets and colonies, all involved with economics base. From mentioned above, it can be seen that the rebuttal from $\mathrm{Hu}$ defended the principles of historical materialism. Even though there were some little drawbacks, the whole argument had firm evidences. As a matter of fact, it clears barriers for the historical materialism (Zhou Yu'e \& Chen Hongming, 1994).

Some scholars considered that the theory of class struggle made capitalists and working class impossible to deal with the conflict. Yet Dai argued that helping with each other ought to stand in equality. It was a joke that two classes without any equality talked about helping and depended on each other. And the fact class struggle, could be traced back earlier than the theory of Marxism. Nevertheless, Marx clearly and profoundly realized it, abstracting it from social relations of history (Tang Wenquan \& Sang Bing, 1990). So Dai thought that it was not Marx who had built the class struggle. It had been existed for long, and Marx just found this law.

However, it was certain that a lot of mistakes were exposed when nationalists 
promoted Marxism. For example, Hu accepted the viewpoint of class struggle of Marxism, but he mistakenly thought that all history had been the history of class struggle. He ignored that before the generation of class, there was society existing without any class. Also with the limitation of class nature, the promotion of Dai took great restriction. He was not able to think spontaneously on the side of the proletariat. And he always showed ambivalence when choosing class reconciliation or class struggle to deal with the conflict between two classes. As for $\mathrm{Zhu}$, in despite that he admitted the confrontation between capital and labor, he still ignored the revolutionary character and advance of workers. Instead, he preferred reconciliation to deal with the problems.

\section{Epilogue}

In conclusion, before great revolution, even though nationalists highly praised Marxism, sparing no effort to promote it, they could not be viewed as real Marxists. Vladimir Lenin once said that theory of class struggle was established by capitalists before instead of Marxism. So generally speaking, it could be accepted by capitalists. Whoever merely admitted class struggle should not be seen as Marxists... Only the one admitting both class struggle and dictatorship of the proletariat may be seen as the Marxist (Marxism and Engels Works Interpreting Office of the Central Committee of the Communist Party of China, 1995). In spite of that, nationalists indeed make a great contribution to the early phase of sanitization of Marxism.

\section{References}

Chen Liugen, \& Peng Hongyun. 陈留根, 彭红望. (2009). Strengthening the Holistic Research of the Early Phase of Sinicization of Marxism 加强早期马克思主义中国化 整体研究. Journal of Pingdingshan University, No. 2, 17-20.

Historical Laboratory of Guangdong Institute of Philosophy and Social Science 广东省哲 学社会科学研究所历史研究室. (1979). Zhu Zhixin Anthology-Part 2 朱执信集. Zhonghua Book Company 中华书局, 691 .

Hu Hanmin. 胡汉民. (1919). Criticism for The Criticism of Historical Materialism 唯物 史观批评之批评. Construction Magazine, No 1, 5 .

Marxism and Engels Works Interpreting Office of the Central Committee of the Communist Party of China (1995). Vladimir Lenin Anthology 列宁选集. Volume 3, People's Publishing Company 人民出版社, 139.

Sun Yat-sen. (1984). Anthology-Volume 1 孙中山选集 第 1 卷. Zhonghua Book Company 中华书局, 236.

Tang Baolin. 唐宝林. (1998). 100 Years of Karl Marx’s Theory in China 马克思主义在 中国 100 年. People’s Publishing Company of Anhui 安徽人民出版社, 135.

Tang Wenquan, \& Sang Bing. 唐文权, 桑兵. (1990). Dai Jitao Anthology 戴季陶集. Central China Normal University Press 华中师范大学出版社, 1046-1047.

Zhou Yu'e, \& Chen Hongming. 周聿峨, 陈红明. (1994). Hu Hanmin 胡汉民. People's Publishing Company of Guangdong 广东人民出版社, 131. 
Submit or recommend next manuscript to SCIRP and we will provide best service for you:

Accepting pre-submission inquiries through Email, Facebook, LinkedIn, Twitter, etc. A wide selection of journals (inclusive of 9 subjects, more than 200 journals)

Providing 24-hour high-quality service

User-friendly online submission system

Fair and swift peer-review system

Efficient typesetting and proofreading procedure

Display of the result of downloads and visits, as well as the number of cited articles Maximum dissemination of your research work

Submit your manuscript at: http://papersubmission.scirp.org/

Or contact chnstd@scirp.org 